\title{
CELL-ENVELOPE PROTEINS OF BORDETELLA PERTUSSIS
}

\author{
R. Parton and A. C. Wardlaw \\ Department of Microbiology, Alexander Stone Building, University of Glasgow \\ Garscube Estate, Bearsden, Glasgow

\section{Plates II AND III}

Sмоотн (phase-I) strains of Bordetella pertussis elicit a variety of unique immunological and physiopathological responses in man and certain laboratory animals. The substances responsible for these effects include the protective antigen (PA), the histamine-sensitising factor (HSF), the lymphocytosis-promoting factor (LPF), the haemagglutinin (HA) and up to eight heat-labile agglutinogens. All of these activities appear to be associated with the cell envelope of the bacterium and to have the properties characteristic of proteins. LPF appears to be associated with fine filamentous structures on the bacterial surface (Morse and Morse, 1970) and the purified LPF obtained by Sato and Arai (1972) consisted mainly of protein. Sato, Arai and Suzuki (1973) found subsequently that LPF preparations also contained high HA activity. Agglutinogen 1 , which is found in all smooth strains of $B$. pertussis and is presumably on the cell surface, also appears to be protein (Onoue, Kitagawa and Yamamura, 1961). Evidence for the localisation of PA and HSF in the envelope and for their protein nature has been reviewed by Wardlaw and Jakus (1966), and Munoz (1971).

During laboratory cultivation of $B$. pertussis, variants arise that lack many of the characters associated with freshly isolated strains (Standfast, 1951). Leslie and Gardner (1931) distinguished four serologically and culturally different groups of variants which they designated phases I, II, III and IV. Phases I and II corresponded to the smooth or pathogenic forms of other bacteria, whereas III and IV resembled the rough, relatively avirulent forms. Currently, only phases I (smooth) and IV (rough) are generally recognised, without differentiation of intermediate phases.

Phase IV (rough) strains lack PA (Kasuga et al., 1954; Aprile, 1972), HSF (Kind, 1953; Aprile, 1972) and agglutinogen I (Eldering, Eveland and Kendrick, 1962). In addition, HA activity is generally lost in laboratory-cultivated strains (Keogh and North, 1948; Standfast, 1951). It may therefore be inferred that phase variation in $B$. pertussis involves changes in the protein composition of the cell envelope.

Another type of variation in B. pertussis called " antigenic modulation" was described by Lacey (1951 and 1960). This was a reversible, phenotypic change affecting the whole population in a culture and was induced by changes in temperature or ionic composition of the growth medium. The normal state, or $\mathrm{X}$-mode, was equivalent to phase $\mathrm{I}$. Organisms with a different antigenic structure (C-mode) were obtained when the sodium ions in the normal growth medium were replaced by magnesium. The $\mathrm{X}$-antigen, which was absent from C-mode cells, appeared to be a protein (Lacey, 1961). C-mode cells differed from $\mathrm{X}$-mode in other properties, including lack of agglutinability by type sera and lack of PA 
and virulence (Lacey, 1951 and 1960; Holt and Spasojevic, 1968; Adams, 1970). Thus, loss of envelope proteins may be involved also in this type of variation.

The work described here concerns the analysis of $B$. pertussis cell-envelope proteins by polyacrylamide-gel electrophoresis in the presence of sodium dodecyl sulphate (SDS). With other bacteria this technique has proved to be very useful for separating and comparing envelope polypeptides according to molecular weight (e.g. Schaitman, $1970 a$ and $b$; Grula and Savoy, 1971). We have therefore used SDS-polysacrylamide-gel electrophoresis to compare the protein profiles of $B$. pertussis phase-I (X-mode) cell envelopes with those of phase IV and C-mode.

\section{MATERIALS AND METHODS}

Strains. A total of eight phase-I and five phase-IV strains of $B$. pertussis was used. Phase-I strains nos. 18323, 18334 and 134, and phase-IV strain no. 11615 had been used in previous investigations (Aprile, 1972; Aprile and Wardlaw, 1973a and $b$ ). A further eight strains were supplied as paired phase-I strains and their corresponding phase-IV variants by Dr Jean Dolby of the Clinical Research Centre, Watford Road, Harrow, Middlesex. These were strains nos. L84 (I), L84 (IV), D3148 (I), D3148 (IV), D30042 (I), D30042 (IV), GL353Z (I) and GL353Z (IV). Strain 3865 (phase I) was also obtained from Dr Dolby.

Growth of cultures. Strains were harvested from Bacto Charcoal Agar (Difco), suspended in $2 \%$ skim milk and kept as vacuum-sealed freeze-dried cultures. For growth of stock cultures, phase-I strains were inoculated on to Charcoal Agar and phase-IV strains on to Trypticase Soy Agar (Oxoid). Both media were dispensed in 50-mm plastic petri dishes which, after inoculation, were sealed with adhesive tape and incubated at $35^{\circ} \mathrm{C}$ in a closed plastic box containing a dish of water to saturate the atmosphere. To prepare cell envelopes, organisms were grown in Roux bottles containing Hornibrook's casamino acid medium, with $0.001 \%(\mathrm{w} / \mathrm{v})$ glutathione in place of cysteine, and incubated for 3 days at $25^{\circ} \mathrm{C}$ with the bottles laid flat. For growth in the C-mode, the $\mathrm{NaCl}(0.5 \% \mathrm{w} / \mathrm{v})$ of Hornibrook medium was replaced by $0.5 \%(\mathrm{w} / \mathrm{v}) \mathrm{MgSO}_{4} .6 \mathrm{H}_{2} \mathrm{O}$, other conditions being the same. Cells were harvested by centrifugation at $6000 \mathrm{~g}$ for $30 \mathrm{~min}$. at $5^{\circ} \mathrm{C}$.

Envelope preparation. Packed cells were resuspended in $0.85 \%(\mathrm{w} / \mathrm{v})$ saline at $4{ }^{\circ} \mathrm{C}$ and, after freezing, were broken by three passages through an X-press (LKB Instruments Ltd, South Croydon, Surrey). After thawing, the resulting suspension was diluted with saline and centrifuged at $100,000 \mathrm{~g}$ for $30 \mathrm{~min}$. The opaque pellet was dispersed in water by means of a syringe fitted with a 23-guage needle and the suspension recentrifuged. This washing procedure was repeated twice more to yield a clear layer containing envelopes overlying an opaque layer of incompletely broken cells and debris. The clear layer was removed, dispersed in a small volume of water and frozen until required for use.

Preparation of samples for electrophoresis. Envelope preparations were adjusted to contain $2 \mathrm{mg}$ per ml protein, as determined by the method of Herbert, Phipps and Strange (1971). To dissolve the envelopes for electrophoresis, $0.5 \mathrm{ml}$ of the sample was added to $0.5 \mathrm{ml}$ of $0.1 \mathrm{M}$ Tris-glycine buffer, $p \mathrm{H} 8.3$, containing $2 \%(\mathrm{w} / \mathrm{v})$ SDS and $2 \%(\mathrm{v} / \mathrm{v})$ $\beta$-mercaptoethanol. The mixtures were usually heated at $100^{\circ} \mathrm{C}$ for $5 \mathrm{~min}$., except in some later experiments, where dissolution was performed at $37^{\circ} \mathrm{C}$ for $30 \mathrm{~min}$. Glycerol (two drops) and $25 \mu 1$ of $0.1 \%(\mathrm{w} / \mathrm{v})$ bromophenol blue as the tracking dye were added.

SDS-polyacrylamide-gel electrophoresis. The method of Davis (1964) modified according to McNiven, Owen and Arbuthnott (1972) was used. Separating gels $(5.5 \times 0.5 \mathrm{~cm})$ contained $11 \cdot 7 \%(\mathrm{w} / \mathrm{v})$ acrylamide and $0.153 \%(\mathrm{w} / \mathrm{v}) \mathrm{NN}^{\prime}$-methylenebisacrylamide (Bis). Stacking gels contained $4 \%(\mathrm{w} / \mathrm{v})$ acrylamide and $1 \%(\mathrm{w} / \mathrm{v})$ Bis. Gels and buffer contained $0 \cdot 1 \%(w / v)$ SDS.

Samples $(25-50 \mu \mathrm{l})$ were layered directly on to the gels and electrophoresis was performed at $1 \mathrm{~mA}$ per gel. For staining and destaining, the method of Weber and Osborn (1969) was used: gels were placed in $0.25 \%$ (w/v) Coomassie Brilliant Blue " $R$ " (Edward Gurr 
Ltd, High Wycombe, Bucks) in methanol, acetic acid and water $(5: 1: 5 \mathrm{v} / \mathrm{v} / \mathrm{v})$. After 90 min. gels were rinsed with water and then destained by soaking in several changes of a mixture containing methanol, acetic acid and water $(2: 3: 35 \mathrm{v} / \mathrm{v} / \mathrm{v})$.

A more exact comparison of different samples was achieved by means of the split-gel technique of Schnaitman (1970b). A strip of "Benchkote" (Whatman Biochemicals Ltd, Maidstone, Kent) was inserted into the stacking gel to separate the two samples.

For molecular weight determinations, marker proteins were run side by side with the samples in split gels. These marker proteins included bovine serum albumin (Sigma Chemical Company, St Louis, Missouri), molecular weight $=67,000$, yeast hexokinase (Sigma Chemical Company), molecular weight $=45,000$, chymotrypsinogen (Miles-Seravac, Maidenhead, Bucks), molecular weight $=25,700$, trypsin (Armour Pharmaceuticals, Eastbourne, Kent), molecular weight $=23,300$, sperm-whale myoglobin (Koch-light, Colnbrook, Bucks), molecular weight $=17,200$ and horse-heart cytochrome C (Koch-Light, Colnbrook, Bucks), molecular weight $=11,700$.

Histamine-sensitising factor. Tests for HSF were done on cells freshly harvested from liquid cultures in Hornibrook's medium and made into vaccine by suspending in $0.85 \%(\mathrm{w} / \mathrm{v}) \mathrm{NaCl}$, heating for $20 \mathrm{~min}$. at $56^{\circ} \mathrm{C}$ and adding thiomersal to $0.1 \mathrm{mg}$ per ml. The HSF tests were done as described by Wardlaw and Jakus (1966) except that mice were of the Charles River CD-I strain. A vaccine made from strain 18334 grown in Hornibrook medium was used as the reference preparation. Results were analysed by the probit method by means of a computer programme.

\section{RESULTS}

Comparison of envelopes of phase-I and phase-IV strains. In initial experiments, the envelopes from four different phase-I strains were compared with that of a phase-IV organism. Figure 1 shows that the protein patterns of the phase-I strains $(18323,3865,18334$ and 134) were all very similar to each other but quite distinct from that of the phase-IV strain 11615.

In later experiments we used four phase-I strains for which the corresponding phase-IV mutants were available. The pairs were examined by the split-gel technique (fig. 2). It is apparent that most of the bands in each pair are closely matched except for a region in the lower part of the gels where consistent differences occurred. A line drawing of the split-gel pattern of a typical phase-I and phase-IV pair is given in fig. 3. The scale on the right hand side is the approximate molecular weights of the bands as determined from marker proteins. The figure shows that the envelopes from both strains were resolved into about 35 bands almost all of which were closely matched. There were in fact, only two significant differences. The most distinct of these was band C which was prominent in the profiles of all eight phase-I strains and undetectable in any of the five phase-IV strains; this band had an apparent molecular weight of about 30,000. Another distinct difference was band B (molecular weight 33,500 ) which was also prominent in phase-I strains whereas phase-IV strains possessed only a minor band in this region.

Phase-I and -IV strains were compared in other combinations in split gels. For example, when phase-I strains were run side by side the band patterns showed no qualitative differences, although small variations were seen in the density of certain bands. The phase-IV envelope profiles were also very similar to each other, although again there was some variation in band density.

$X$-mode and C-mode organisms. Having shown consistent differences 
between phase-I and phase-IV strains, X-mode and C-mode cells were compared to see if similar differences could be demonstrated. These experiments were done with strains no. 18334, L84(I) and 18323 grown in the normal medium to give X-mode cells or in the medium of high magnesium content to obtain the C-mode. Cells from each mode were tested for HSF and typical results are given in the table. Although each of the cell preparations contained HSF, the level was much reduced in the C-mode. With strain 18334, the C-mode culture had only $3 \%$ of the HSF activity of the X-mode when equal numbers of cells were compared. The corresponding value for L84(I) was $2.5 \%$.

When the electrophoretic patterns of envelope polypeptides from C-mode

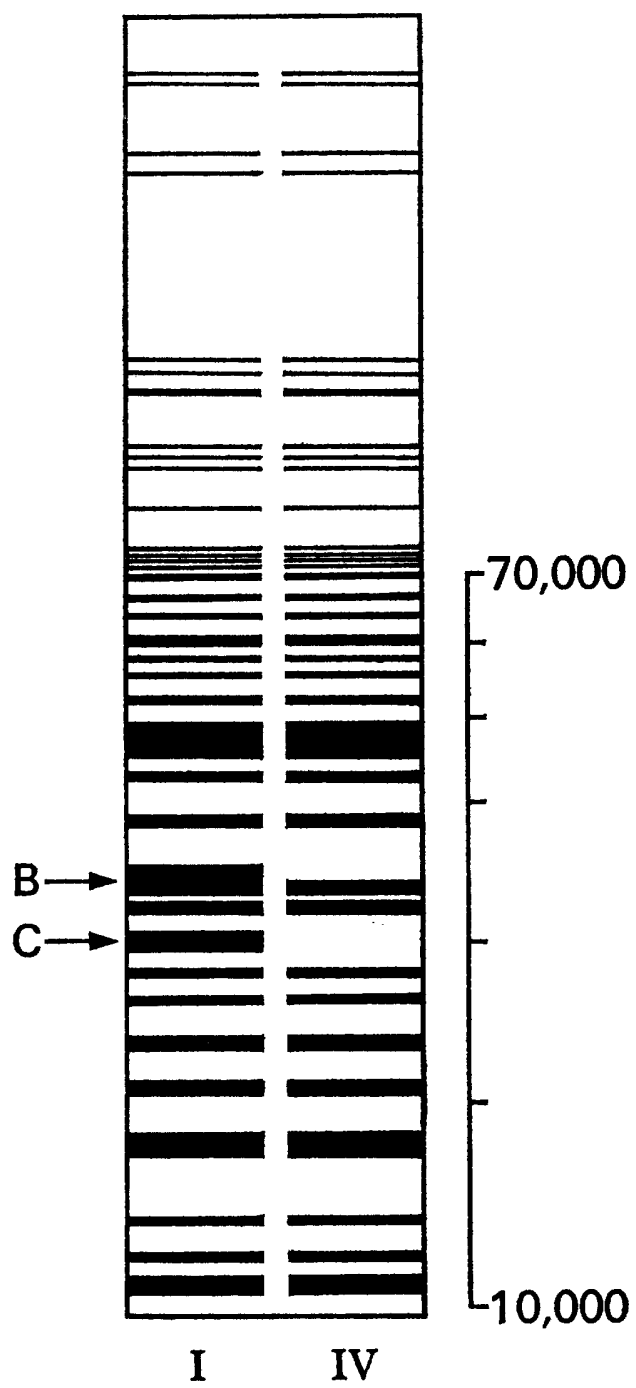

Fig. 3.-Line drawing of the band patterns observed in the split gels shown in fig. 2. The scale on the right shows the approximate molecular weights of the polypeptide bands as determined from marker proteins. 
cells of strain L84(I) were compared with those of the X-mode, they were found to lack band C, and band B was much diminished or absent (fig. 4). They were thus indistinguishable from the envelopes of phase-IV cells grown on the normal medium. Similar results were obtained with C-mode cells of strains no. 18334 and 18323.

The reports in the literature that deal with X-mode and C-mode cultures of $B$. pertussis refer mainly to phase-I strains although Lacey (1960) studied what he termed "highly degraded" mutants. We thought it would be of interest to see if the protein profiles of our phase-IV strains would be affected by growth under C-mode conditions. So far, this has been investigated only with L84(IV) and fig. 4 shows there was no change in envelope profile.

Temperature of dissolution. In all the above experiments, the bacterial envelopes were dissolved at $100^{\circ} \mathrm{C}$ for $5 \mathrm{~min}$. It is known, however, from work with other bacteria that different band patterns may arise when different temperatures are used for this. We therefore compared the patterns described

TABLE

Histamine-sensitising factor* in X-mode and C-mode cells of Bordetella pertussis

\begin{tabular}{|c|c|c|c|c|}
\hline $\begin{array}{c}\text { Cell } \\
\text { preparation }\end{array}$ & $\begin{array}{c}\text { Challenge dose } \\
\text { (opacity } \\
\text { units) }\end{array}$ & $\begin{array}{c}\text { Number of } \\
\text { survivors after } \\
\text { histamine challenge } \dagger\end{array}$ & $\begin{array}{l}\text { Potency } \\
\text { related to } \\
\text { reference }\end{array}$ & $\begin{array}{l}95 \% \\
\text { Confidence } \\
\text { limits }\end{array}$ \\
\hline $\begin{array}{l}\text { Reference vaccine, } \\
\text { strain } 18334\end{array}$ & $\begin{array}{l}4 \\
2 \\
1 \\
0 \cdot 5\end{array}$ & $\begin{array}{l}0 \\
1 \\
3 \\
5\end{array}$ & 1.00 & $\cdots$ \\
\hline $\begin{array}{l}\text { Strain } \\
\quad 18334, X \text {-mode }\end{array}$ & $\begin{array}{l}2 \\
1 \\
0.5 \\
0 \cdot 25\end{array}$ & $\begin{array}{l}0 \\
0 \\
2 \\
9\end{array}$ & 1.74 & $0.98,3.03$ \\
\hline $\begin{array}{l}\text { Strain } \\
\quad 18334, \text { C-mode }\end{array}$ & $\begin{array}{c}20 \\
10 \\
5 \\
2 \cdot 5\end{array}$ & $\begin{array}{l}3 \\
7 \\
8 \\
8\end{array}$ & 0.058 & $0.031,0.098$ \\
\hline $\begin{array}{l}\text { Strain } \\
\text { L84, X-mode }\end{array}$ & $\begin{array}{l}2 \\
1 \\
0 \cdot 5 \\
0 \cdot 25\end{array}$ & $\begin{array}{l}0 \\
0 \\
1 \\
4\end{array}$ & $3 \cdot 11$ & $1 \cdot 71,5 \cdot 93$ \\
\hline $\begin{array}{l}\text { Strain } \\
\text { L84, C-mode }\end{array}$ & $\begin{array}{c}20 \\
10 \\
5 \\
2 \cdot 5\end{array}$ & $\begin{array}{r}1 \\
1 \\
9 \\
10\end{array}$ & 0.078 & $0.043,0.132$ \\
\hline
\end{tabular}

* A full description of the HSF test is given by Wardlaw and Jakus (1966).

$\uparrow$ Each group contained 10 mice. 
above with those obtained when envelopes were dissolved at $37^{\circ} \mathrm{C}$ for $30 \mathrm{~min}$. Phase-I envelopes dissolved under the two conditions were run in split gels (fig. 5). This figure and the corresponding line drawing (fig. 6) show that the majority of the bands were identical in the two preparations. However, band $\mathrm{C}$ in the envelopes that had been dissolved at $100^{\circ} \mathrm{C}$ was absent from those dissolved at $37^{\circ} \mathrm{C}$, and band $\mathrm{B}$ was less apparent. Thus, with envelopes dissolved at $37^{\circ} \mathrm{C}$ this region of the gel was indistinguishable from the envelope profiles of phase-IV and $\mathrm{C}$-mode cells dissolved at $100^{\circ} \mathrm{C}$. However, the envelopes dissolved at $37^{\circ} \mathrm{C}$ showed two prominent bands labelled $\mathrm{D}$ and $\mathrm{E}$ with molecular weights 23,000 and 21,000 respectively. These bands were much stronger than the corresponding bands in the profile of envelopes dissolved

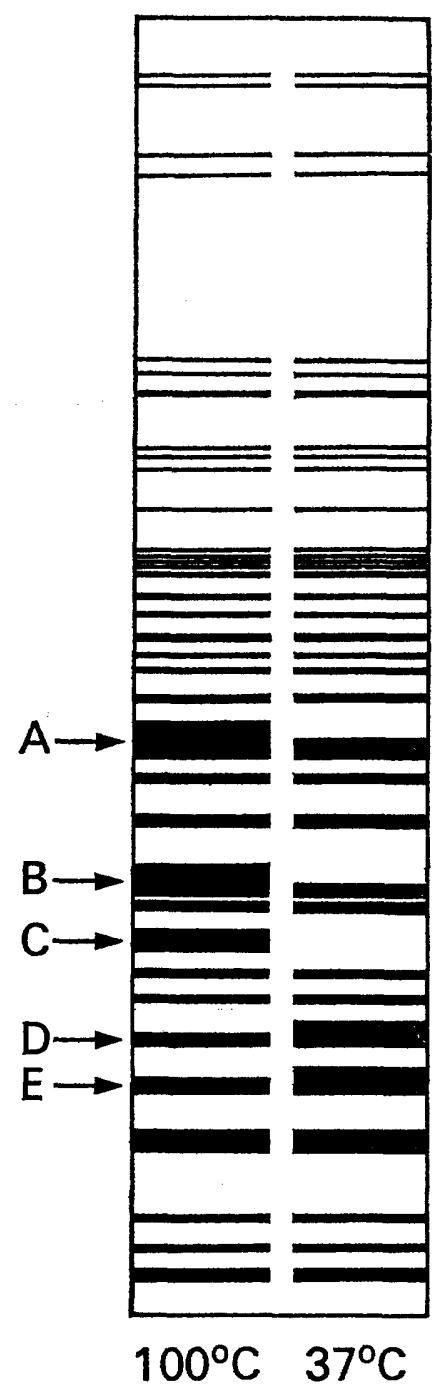

FIG. 6.-Line drawing of the band patterns observed in the split gel shown in fig. 5 . 
at $100^{\circ} \mathrm{C}$. Another difference in these gels was that band $\mathrm{A}$ (molecular weight 46,000 ) was a major feature of envelopes dissolved at $100^{\circ} \mathrm{C}$ but not those dissolved at $37^{\circ} \mathrm{C}$. This same difference was found in phase-IV envelopes dissolved under the two conditions although no other bands were apparently affected.

From the above observations, it seemed possible that the polypeptides in bands $B$ and $C$ and in bands $D$ and $E$ were in some way related but were behaving differently when dissolved under the two conditions. This was confirmed in the following manner: $100-\mu 1(100-\mu \mathrm{g})$ samples of strain 3865 envelopes dissolved at $37^{\circ} \mathrm{C}$, were applied to gels and run in the normal way. The gels were then sliced transversely so that one slice contained bands D and E. The slices were subsequently cut in semi-circular halves and chopped finely with a razor blade. Polypeptides were eluted by soaking in $150 \mu 1$ of dissolving buffer $(0.05 \mathrm{M}$ Tris-glycine buffer $p \mathrm{H} 8.3$ containing $1 \%$ SDS and $1 \%$ $\beta$-mercaptoethanol) at room temperature for $2 \mathrm{~h}$. One half of the sample was then heated to $100^{\circ} \mathrm{C}$ for $5 \mathrm{~min}$. while the other half remained unheated as a control. Glycerol and bromophenol blue were added. The samples were applied to separate and split gels and the electrophoretic procedure was repeated. Most of the material from bands $\mathrm{D}$ and $\mathrm{E}$ was now found to migrate with bands $\mathrm{B}$ and $\mathrm{C}$, i.e., heating in the buffer apparently increased the molecular weight of these components. It therefore appears that most of the polypeptides in Bands $D$ and $E$ are identical with those in bands $B$ and $C$ and that the different mobilities arise from the different conditions of solution. Polypeptides from other parts of the gel were unaffected by treatment at the high temperature.

\section{Discussion}

B. pertussis, in common with other Gram-negative bacteria whose cell envelopes have been analysed by SDS-polyacrylamide gel electrophoresis, shows a complex pattern of polypeptide bands. About 35 separate components were resolved, with molecular weights ranging from 10,000 to well over 70,000 . It will be appreciated, however, that this represents the minimum number of different polypeptide chains in the pertussis envelope, because each band may contain several different polypeptides of similar molecular weight.

Altogether 13 pertussis strains were examined, and all showed remarkably similar band patterns, but with a consistent difference between phase I and phase IV. The eight phase-I strains gave patterns that were qualitatively indistinguishable, even in split gels in which an exact comparison of such complex patterns is possible. This result was not expected, because the phase-I strains were known to possess various combinations of heat-labile agglutinogens which might have appeared as differences in band patterns. For example, strain no. 18334 (a Connaught vaccine-strain) has antigens 1, 2, 4, whereas no. 134 (Pillemer strain) has antigens 1,3 and no. 18323 (the mouse-protectiontest challenge-organism) has antigens 1, 2, 3, 4. However, this identity of band patterns does not necessarily mean that the heat-labile agglutinogens (assumed to be proteins) are present in amounts too small to be detected. It 
may be simply that their polypeptide components have molecular weights coincident with those of other membrane proteins.

The five phase-IV strains gave band patterns that closely matched each other. They also matched closely those of phase-I strains in all but two regions of the gel. Thus the eight phase-I strains possessed two major components, band C (molecular weight 30,000) and band B (molecular weight 33,500). band $\mathrm{C}$ was completely absent from the phase-IV variants whereas band $\mathrm{B}$ was either absent or much diminished in amount and more difficult to define precisely.

Phase variation in B.pertussis, although resembling in some ways the smooth to rough variation in Enterobacteriaceae, appears to be considerably more complicated (Aprile, 1972). It may involve changes not only in the serological specificity of the lipopolysaccharide (LPS) but also in growth requirements. However, of greater relevance to the present work is the loss of PA, HSF, LPF, HA and heat-labile agglutinogens-all components of the phase-I cell envelope and having the properties of proteins. Several authors have suggested that some or all of these activities may represent different manifestations of the same molecule rather than of several distinct proteins (Levine and Pieroni, 1966; Sato and Arai, 1972; Munoz et al., 1973, Sato et al., 1973). It is in this context therefore that the finding of a consistent deletion of one and possibly two polypeptide bands during phase variation is of greatest interest. It is possible that the deleted band or bands may represent the missing biological activities although it will be difficult to prove this directly. Unfortunately the SDS-mercaptoethanol treatment of the envelopes that is necessary to prepare the samples for electrophoresis is a denaturing process. We have found that HSF activity, at least, is totally destroyed when vaccines are treated with $1 \%(\mathrm{w} / \mathrm{v}) \mathrm{SDS}$ for $1 \mathrm{~h}$ at $20^{\circ} \mathrm{C}, 37^{\circ} \mathrm{C}$ or $56^{\circ} \mathrm{C}$. It may, however, be possible to use the electrophoretic technique to monitor the amount of bands $\mathrm{B}$ and $\mathrm{C}$ in envelope fractions, prepared by less drastic methods, and see if this is correlated with the biological activities of the fractions.

The observations with X-mode and C-mode cells are fully consistent with the hypothesis that bands $\mathrm{B}$ and $\mathrm{C}$ are somehow connected with the biologicallyactive envelope proteins that are lost during phase variation. Phase I strains grown as C-mode cells (in "high-magnesium " medium) gave gel patterns that lacked bands $B$ and $C$ and were thus identical in this respect with phase-IV organisms. The HSF content of C-mode cells was much diminished in comparison with that of $\mathrm{X}$-mode cultures grown in parallel. In addition, $\mathrm{C}$-mode cultures are known to lack PA and certain agglutinogens (Lacey, 1951 and 1960; Holt and Spasojevic, 1968; Adams, 1970). This again may associate bands $\mathrm{B}$ and $\mathrm{C}$ with some of the important immunological and physiopathological components of the pertussis cell-envelope.

Additional observations on the proteins contained in bands $\mathrm{B}$ and $\mathrm{C}$ were made during experiments to determine suitable conditions of dissolution for envelope proteins. When phase-I envelopes were dissolved in SDS-mercaptoethanol at $37^{\circ} \mathrm{C}$ for $30 \mathrm{~min}$., instead of the usual $100^{\circ} \mathrm{C}$ for $5 \mathrm{~min}$., band $\mathrm{C}$ and most if not all of band B were absent from the subsequent electrophoretic 


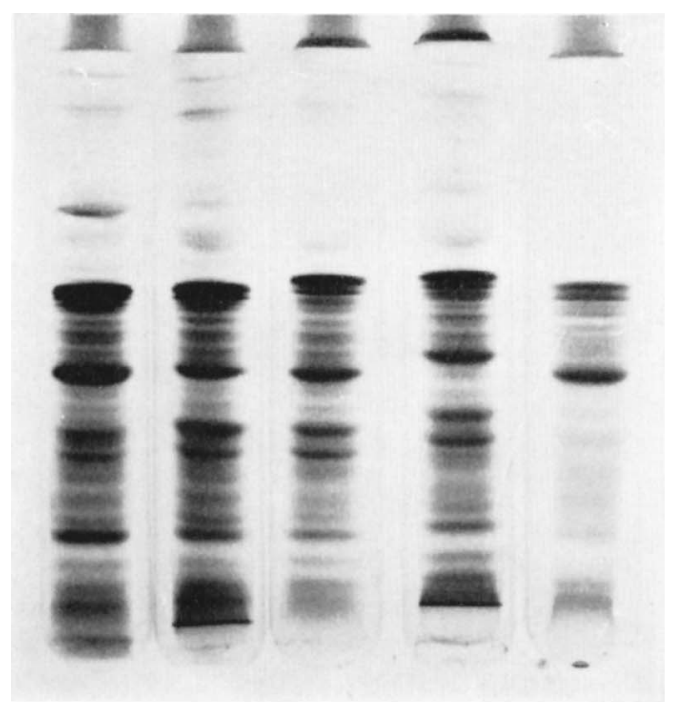

(a) (b) (c)

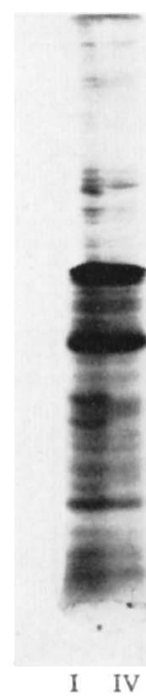

(a)

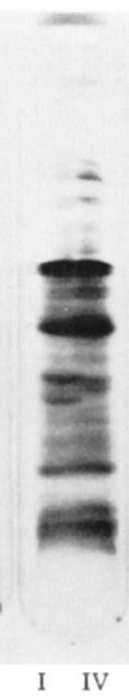

(b)

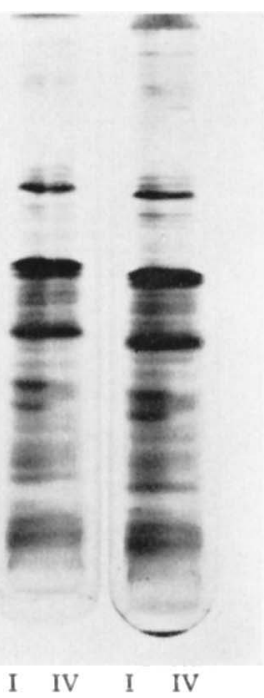

(c)

(d)

FIG. 1.

FIG. 2.

FIG. 1.-SDS-polyacrylamide-gel electrophoresesis of envelope polypeptides of Bordetella pertussis phase-I strains $(a)$ no. $18323,(b)$ no. 3865 , (c) no. 18334 , (d) no. 134 , and phase-IV strain (e) no. 11615 . Envelopes were dissolved at $100^{\circ} \mathrm{C}$ for $5 \mathrm{~min}$.

FIG. 2.-SDS-polyacrylamide-gel electrophoresis of envelope polypeptides of phase-I and corresponding phase-IV strains compared by the split-gel technique: (a) no. L84, (b) no. D3148, (c) no. D30042, $(d)$ no. GL353Z. Envelopes were dissolved at $100^{\circ} \mathrm{C}$ for $5 \mathrm{~min}$. 


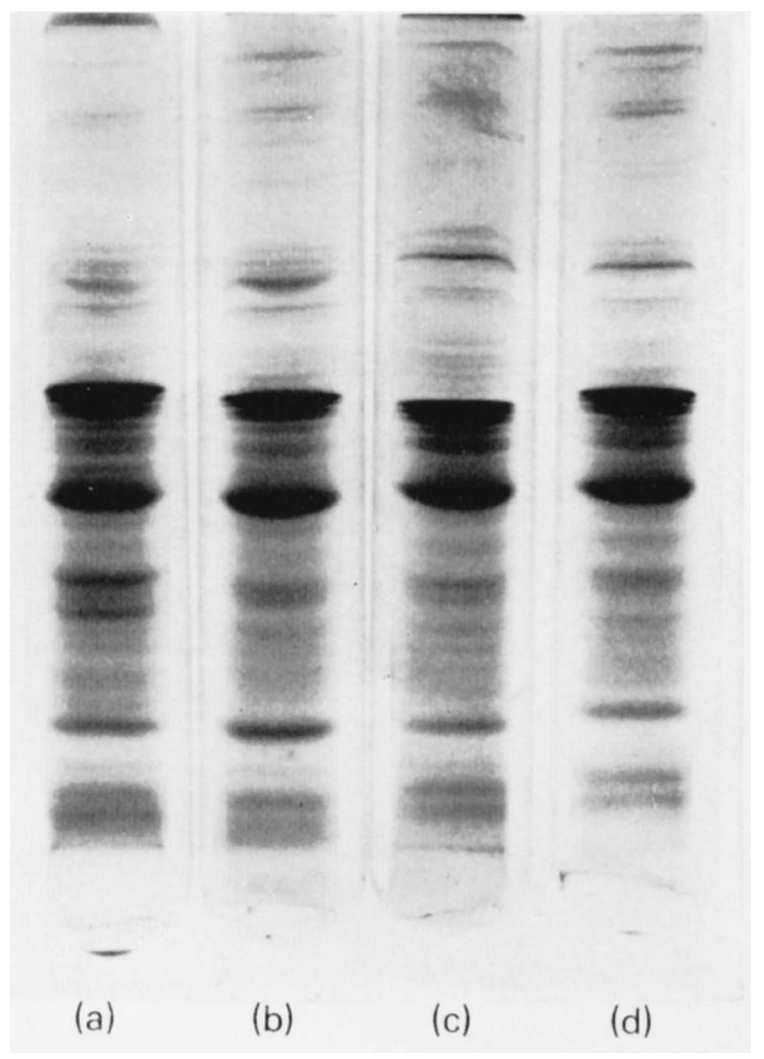

FIG. 4.

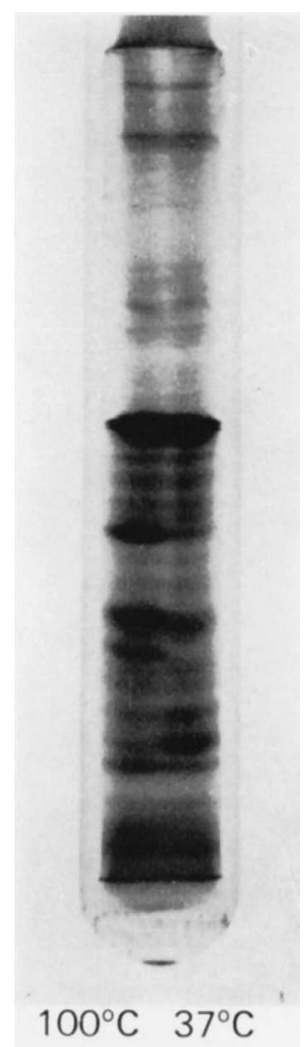

FIG. 5.

FIG. 4.-SDS-polyacrylamide-gel electrophoresis of envelope polypeptides of $B$. pertussis strains L84 (I) and L84 (IV) grown in the presence of either $\mathrm{NaCI}$ or $\mathrm{MgSO}_{4}(a)$ phase $\mathrm{I}, \mathrm{NaCl},(b)$ phase I, $\mathrm{MgSO}_{4},(c)$ phase IV, $\mathrm{NaCl},(d)$ phase IV, $\mathrm{MgSO}_{4}$. Envelopes were dissolved at $100^{\circ} \mathrm{C}$ for $5 \mathrm{~min}$.

FIG. 5.-SDS-polyacrylamide-gel electrophoresis of the envelope proteins of $B$. pertussis strain 3865 dissolved at $100^{\circ} \mathrm{C}$ for $5 \mathrm{~min}$. or at $37^{\circ} \mathrm{C}$ for $30 \mathrm{~min}$. and compared in a split gel. 
pattern. In addition, two prominent bands, $\mathrm{D}$ and $\mathrm{E}$, were now present at 23,000 and 21,000 respectively. The interesting observation was made that when bands $\mathrm{D}$ and $\mathrm{E}$ were sliced from the gel and the polypeptides eluted, they gave rise to bands $\mathrm{B}$ and $\mathrm{C}$ if heated at $100^{\circ} \mathrm{C}$ in SDS-mercaptoethanol and re-run. It may seem paradoxical that the apparent molecular weight should increase as a result of treatment at $100^{\circ} \mathrm{C}$. However, the same phenomenon has been observed with Escherichia coli cell-envelope proteins (Bragg and Hou, 1972; Inouye and Yee, 1973; Schnaitman, 1973). Osborn et al. (1972) also found variability in the protein pattern of Salmonella typhimurium envelopes after dissolution under different heating conditions. Schnaitman (1973) has suggested that the faster moving bands may represent protein that has not fully reacted with SDS and which, after heating, is converted to the slower-moving " rigid-rod" conformation characteristic of protein-SDS complexes.

Among recent studies of envelope proteins of other bacteria are those of Robinson and Tempest (1973). They found marked differences in the envelope proteins of Klebsiella aerogenes grown under various conditions of nutrient limitation in chemostat cultures. Schnaitman (1970a), however, found only minor changes in the envelope-protein spectra of $E$. coli grown in batch culture on different carbon sources. Other workers have reported no changes in the electrophoretic profile of whole-cell proteins or membrane proteins of various organisms after changes in growth medium (Razin and Rottem, 1967; Theodore, King and Cole, 1969; Morris, 1973). The only previous comparison of smooth and rough variants by an electrophoretic method we have noted is that of Morris with Brucella species. However, no differences were observed in the protein spectra obtained from whole cells of the smooth and rough organisms.

\section{SUMMARY}

Cell-envelope polypeptides of eight phase-I and five phase-IV strains of Bordetella pertussis were compared by SDS-polyacrylamide gel electrophoresis. All phase-I strains gave a strikingly similar but complex pattern of protein bands, which did not appear to vary with known differences in heat-labile agglutinogens. Phase-IV strains gave the same pattern as phase-I strains, except that one band was missing and another was either much reduced or absent.

Envelopes from phase-I strains grown in Hornibrook medium rich in $\mathrm{Mg}^{2+}$ ions to produce " antigenically-modulated" C-mode cells gave a pattern of bands indistinguishable from phase-IV strains. A phase-IV strain grown in the high- $\mathrm{Mg}^{2+}$ medium gave the same pattern of bands as when grown in unmodified Hornibrook medium. We suggest that the two polypeptide bands that show changes may be responsible for one or more of the immunological or physiopathological activities that are lost during phase variation and antigenic modulation in $B$. pertussis.

This project was supported by a grant from the Medical Research Council. 


\section{REFERENCES}

ADAMS, G. J. 1970. Intracerebral infection of mice with high-virulence and low-virulence strains of Bordetella pertussis. J. med. Microbiol., 3, 1 .

APRILE, M. A. 1972. A reexamination of phase IV Bordetella pertussis. Can. J. Microbiol., $18,1793$.

Aprile, M. A. ANd Wardlaw, A. C. 1973a. Immunochemical studies on the lipopolysaccharides of Bordetella pertussis. Can. J. Microbiol., 19, 231.

Aprile, M. A. AND Wardlaw, A. C. $1973 b$. Availability and specificity of lipopolysaccharide on the surface of $56^{\circ} \mathrm{C}$ heated Bordetella pertussis. Can. J. Microbiol., 19, 536.

BRAGG, P. D. AND Hou, C. 1972. Organization of proteins in the native and reformed outer membrane of Escherichia coli. Biochim. biophys. Acta, 274, 478.

Davis, B. J. 1964. Disc electrophoresis. II. Method and application to human serum proteins. Ann. N.Y. Acad. Sci., 121, 404.

Eldering, G., Eveland, W. C. AND Kendrick, P. L. 1962. Fluorescent antibody staining and agglutination reactions in Bordetella pertussis cultures. J. Bact., 83, 745.

Grula, E. A. ANd Savoy, C. F. 1971. A detergent-polyacrylamide gel system for electrophoretic resolution of membrane and wall proteins. Biochem. biophys. Res. Commun., 43, 325.

Herbert, D., Phipps, P. J. and Strange, R. E. 1971. In Methods in microbiology, vol. 5B, edited by J. R. Norris and D. W. Ribbons, London and New York, p. 249.

Holt, L. B. AND Spasojevic, V. 1968. The role of surface antigens in the protective potency of Bordetella pertussis suspensions as measured by the intracerebral challenge technique in mice. J. med. Microbiol., 1, 119.

INOUYE, M. AND YeE M. L. 1973. Homogeneity of envelope proteins of Escherichia coli separated by gel electrophoresis in sodium dodecyl sulfate. J. Bact., 113, 304.

Kasuga, T., Nakase, Y., Ukishima, K. and Takatsu, K. 1954. Studies on Haemophilus pertussis. Part IV. Preventive potency of each phase organisms of Haemophilus pertussis in mice. Kitasato Archs exp. Med., $27,49$.

KeOGh, E. V. AND North, E. A. 1948. The haemagglutinin of Haemophilus pertussis. I. Haemagglutinin as a protective antigen in experimental murine pertussis. Aust. J. exp. Biol. med. Sci., 26, 315.

KIND, L. S. 1953. The altered reactivity of mice after immunization with Haemophilus pertussis vaccine. J. Immun., 70, 411.

LACEY, B. W. 1951. Antigenic modulation of Haemophilus pertussis. J. gen. Microbiol., 5 , xxi.

LACEY, B. W. 1960. Antigenic modulation of Bordetella pertussis. J. Hyg., Camb., 58, 57.

LACEY, B. W. 1961. Non-genetic variation of surface antigens in Bordetella and other microorganisms. Symp. Soc. gen. Microbiol., 11, 343.

Leslie, P. H. ANd Gardner, A. D. 1931. The phases of Haemophilus pertussis. J. Hyg., Camb., 31, 423.

LeVIne, L. AND Pieroni, R. E. 1966. A unitarian hypothesis of altered reactivity to stress mediated by Bordetella pertussis. Experientia, 22, 797.

McNiven, A. L. C., Owen, P. AND Arbuthnott, J. P. 1972. Multiple forms of staphylococcal alpha-toxin. J. med. Microbiol., 5, 113.

MoRRIS, J. A. 1973. The use of polyacrylamide gel electrophoresis in taxonomy of Brucella. J. gen. Microbiol., 76, 231.

Morse, J. H. AND Morse, S. I. 1970. Studies on the ultrastructure of Bordetella pertussis. I. Morphology, origin and biological activity of structures present in the extracellular fluid of liquid cultures of Bordetella pertussis. J. exp. Med., 131, 1342.

Munoz, J. 1971. Protein toxins from Bordetella pertussis. In Microbial toxins, vol. 2A, edited by S. Kadis, T. C. Montie and S. J. Ajl, New York and London, p. 271.

Munoz, J., Bergman, R. K., Cole, R. L. ANd Ayers, J. C. 1973. Possible identity of the histamine sensitizing factor (HSF) and lymphocyte promoting factor (LPF) from Bordetella pertussis. Abstr. Am. Soc. Microbiol., 73, 92. 
Onoue, K., Kitagawa, M. And Yamamura, Y. 1961. Chemical studies on cellular components of Bordetella pertussis. I. Purification and properties of agglutinogen. J. Bact., 82, 648.

Osborn, M. J., Gander, J. E., Parisi, E. And Carson, J. 1972. Mechanism of assembly of the outer membrane of Salmonella typhimurium. Isolation and characterization of cytoplasmic and outer membrane. J. biol. Chem., 247, 3962.

RAZIN, S. AND RoTTEM, S. 1967. Identification of Mycoplasma and other micro-organisms by polyacrylamide-gel electrophoresis of cell proteins. J. Bact., 94, 1807.

RoBINSON, A. AND TEMPEST, D. W. 1973. Phenotypic variability of the envelope proteins of Klebsiella aerogenes. J. gen. Microbiol., 78, 361.

Sato, Y. AND ARAI, H. 1972. Leucocytosis-promoting factor of Bordetella pertussis. I. Purification and characterization. Infect. Immun., 6, 899.

Sato, Y., ARAI, H. AND SuzUKI, K. 1973. Leucocytosis-promoting factor of Bordetella pertussis. II. Biological properties. Infect. Immun., 7, 992.

Schnartman, C. A. $1970 a$. Protein composition of the cell wall and cytoplasmic membrane of Escherichia coli. J. Bact., 104, 890.

Schnatman, C. A. $1970 b$. Comparison of the envelope protein compositions of several Gram-negative bacteria. J. Bact., 104, 1404.

Schnatrman, C. A. 1973. Outer membrane proteins of Escherichia coli. I. Effect of preparative conditions on the migration of protein in polyacrylamide gels. Archs Biochem. Biophys., 157, 541.

Standfast, A. F. B. 1951. The phase I of Haemophilus pertussis. J. gen. Microbiol., 5, 531.

Theodore, T. S., KING, J. R. AND Cole, R. M. 1969. Identification of L-forms by polyacrylamide-gel electrophoresis. J. Bact., 97, 495.

WARDLAW, A. C. AND JAKUS, C. M. 1966. The inactivation of pertussis protective antigen, histamine sensitizing factor, and lipopolysaccharide by sodium metaperiodate. Can. J. Microbiol., 12, 1105.

WEBER, K. AND OSBORN, M. 1969. The reliability of molecular weight determinations by dodecyl sulphate-polyacrylamide gel electrophoresis. J. biol. Chem. 244, 4406. 